\title{
Pengaruh Model Pembelajaran Kooperatif terhadap Sikap Empati Siswa
}

\author{
Muhammad Syaekhu ${ }^{1^{*}}$, Didik Subhakti Prawira Raharja ${ }^{2}$, Riza Sukma Fauzi ${ }^{3}$ \\ Maya Nurhayati ${ }^{4}$ \\ ${ }^{123}$ Universitas Majalengka, Majalengka, Indonesia , 45418 \\ didikspraharja@unma.ac.id, fauzi@unma.ac.id, mayanurhayati@unma.ac.id
}

\begin{abstract}
The low interaction that occurs due to technological changes tends to be individualistic and results in empathy. Low empathy can lead to various deviant behaviors that need to be trained and familiarized with group learning. The purpose of this study was to determine the effect of the cooperative learning model on students' empathy attitudes. This research was conducted at MI PUI Tenajar Lor 2 school with the sample selected using two stage random sampling, with experimental design pre test post test control group design method, then an empathy questionnaire was used to measure students' empathy. The results showed that there was a difference in influence between the experimental group with the jingsaw type cooperative method and the control group with the conventional method, thus as an alternative to developing students' empathy, the jingsaw type cooperative method could be used. However, further research is needed to complete this research.
\end{abstract}

Keywords: Learning, Model Cooperative, Jingsaw, Empathy

\begin{abstract}
ABSTRAK. Rendahnya interaksi yang terjadi akibat perubahan teknologi cenderung menjadi individualistis dan berakibat pada empati. Rendahnya empati dapat mengakibatkan berbagai prilaku yang menyimpang sehingga perlu dilatih dan dibiasakan dengan pembelajaran yang berkelompok. Tujuan penelitian ini untuk mengetahui pengaruh dari model pembelajaran Kooperatif terhadap sikap empati siswa. Penelitian ini dilakukan di sekolah MI PUI Tenajar Lor 2 dengan sample dipilih menggunakan two stage random sampling, dengan metode ekperiment desain pre test post test control group desain, kemudian angket empati digunakan untuk mengukut empati siswa. Hasil penelitian menunjukkan adanya perbedaan pengaruh antara kelompok emperiment dengan metode kooperatif type jingsaw dengan kelompok control dengan metode konvensional, dengan demikian sebagai alternatif untuk mengembangkan sikap empati siswa dapat digunakan metode kooperatif tipe jingsaw. Namun perlu di lakukan penelitian lanjut untuk melengkapi penelitian ini.
\end{abstract}

Kata Kunci: Pembelajaran, Model Kooperatif, Jingsaw, Empati

\section{PENDAHULUAN}

Berbagai bentuk kekerasan dan konflik yang terjadi belakangan ini merupakan akibat dari minimnya budaya empati di masyarakat Indonesia. Rendahnya empati ini menurut Aprinus dikarenakan akar kultural Indonesia tidak dilandasi dengan akar kultural yang mapan (https://ugm.ac.id/id/berita/7649-empati-masyarakat-indonesia-sangatkurang). Perilaku-perilaku tersebut di atas menunjukkan rendahnya empati, karena ketiadaan empati dapat memunculkan kehidupan perilaku menyimpang seperti menganiaya, menghina, mencuri bahkan membunuh orang lain. Ketidakmampuan 


\section{Journal Respecs}

seseorang untuk merasakan penderitaan orang lain menyebabkannya mampu melakukan tindakan kriminal.

Pada umumnya gejala masalah pribadi dan sosial ini juga tampak dalam perilaku keseharian. Sikap-sikap individualistis, egoistis, acuh tak acuh, kurangnya rasa tanggung jawab, malas berkomunikasi dan berinteraksi merupakan fenomena yang menunjukkan adanya kehampaan nilai sosial dalam kehidupan sehari-hari.

Pentingnya perilaku prososial mempunyai dampak positif bagi kehidupan bermasyakat. Dampak positif dari adanya perilaku prososial yaitu adanya rasa keharmonisan, kedamaian, menyanyangi antar sesama, menghargai antar sesama. Namun pada kenyataannya di era globalisasi saat ini bangsa Indonesia sedang mengalami krisis sosial (Solekhah, 2018).

Berdasarkan pengamatan Auliyah dan Flurentin (2016: 20) mengungkapkan siswa kelas 6 merasa lebih berkuasa dan bisa menyuruh adik tingkatnya. Selain itu juga masih ada siswa yang membuat kelompok - kelompok tertentu dalam satu kelas, ada juga beberapa siswa yang dikucilkan di dalam kelas. Salah satu faktor penyebab kasus-kasus seperti itu adalah tingkat empati individu yang rendah.

Hasil penelitian selama beberapa tahun menunjukkan bahwa tingkat empati yang tinggi dalam setiap hubungan antar manusia merupakan faktor paling besar yang mendorong terjadinya perubahan dan proses belajar (Rogers, 1980: 139). Oleh karena itu, telah timbul kecenderungan dalam dunia pendidikan untuk lebih meningkatkan empati.

Menurut Timpe (1999: 283-284) ada tiga metode yang dapat digunakan untuk menambah kepekaan perasaan sehingga empati seseorang meningkat, yang pertama dengan melakukan introspeksi dan menggunakan teman terpercaya sebagai tempat berkaca diri. Metode yang kedua dengan mencari bantuan dari orang-orang profesional, dan yang ketiga melalui interaksi dengan kelompok yang mengikuti pelatihan kepekaan perasaan.

Metode pembelajaran kooperatif menawarkan pembelajaran dengan saling bekerjasama dan berusaha memecahkan masalah didalam kelompok secara Bersamasama. Bahkan beberapa penelitian mengenai penerapan model kooperatif terbukti meningkatkan prilaku interaksi sosial siswa (Raharja, 2014).

Penggunaan model kooperatif menjadi salah satu stimulasi untuk mengembangkan kemampuan empati pada anak, terutama anak tahap akhir. Peran teman 
sebaya menjadi sangat penting saat berinteraksi untuk memahami adanya perbedaan di antara mereka sehingga baik untuk perkembangan mental dan emosi anak, terutama empati (Alsa, 2009)

Dengan demikian, untuk menumbuhkan sikap empati siswa perlu diajarkan sedini mungkin, dan diharapkan pada tahapan akhir anak dapat melekat sebagai bagian dari pengalaman untuk kehidupan yang akan datang, dan hal tersebut akan di cobakan melalui pembelajaran dengan model kooperatif tipe jingsaw.

\section{METODE PENELITIAN}

Dalam penelitian ini, peneliti ingin mengetahui sebab akibat yang di timbulkan dari model kooperatif tipe jingsaw dan model konvensional terhadap sikap empati siswa. oleh sebab ingin mengetahui sebab akibat yang ditimbulkan maka metode penelitian yang digunakan adalah metode eksperimen.

Dalam mempermudah alur dalam penelitian maka diperlukan suatu desain penelitian yang berfungsi digunakan sebagai acuan, adapun desain penelitian yang digunakan dalam penelitian ini menggunakan The Randomized Pretest-Posttest Control Group Design. Desain ini melibatkan kelompok kontrol Fraenkel \& Wallen (1993).

Penelitian ini dilakukan di Sekolah MI PUI Tenajar Lor 2, Pemilihan sampel dalam penelitian ini menggunakan teknik Two-Stage Random Sampling, yang melibatkan cluster random sampling dan simple random. Cluster random dipilih untuk menentukkan kelas yang menjadi sampel dan simple random di gunakan untuk menentukkan kelas eksperimen dan kelas kontrol. Instrumen yang digunakan yaitu angket untuk mengukur empati, dan pengolahan data menggunakan uji paired sample T-test dengan aplikasi SPSS.

\section{HASIL DAN PEMBAHASAN}

\section{Hasil penelitian}

Berdasarkan hasil penelitian yang dilakukan, dan setelah data terkumpul kemudian dilanjutkan dengan pengolahan data, maka hasil yang diperoleh adalah sebagai berikut. 
Tabel 1

Hasil Uji Paired Sample T - Test Empati

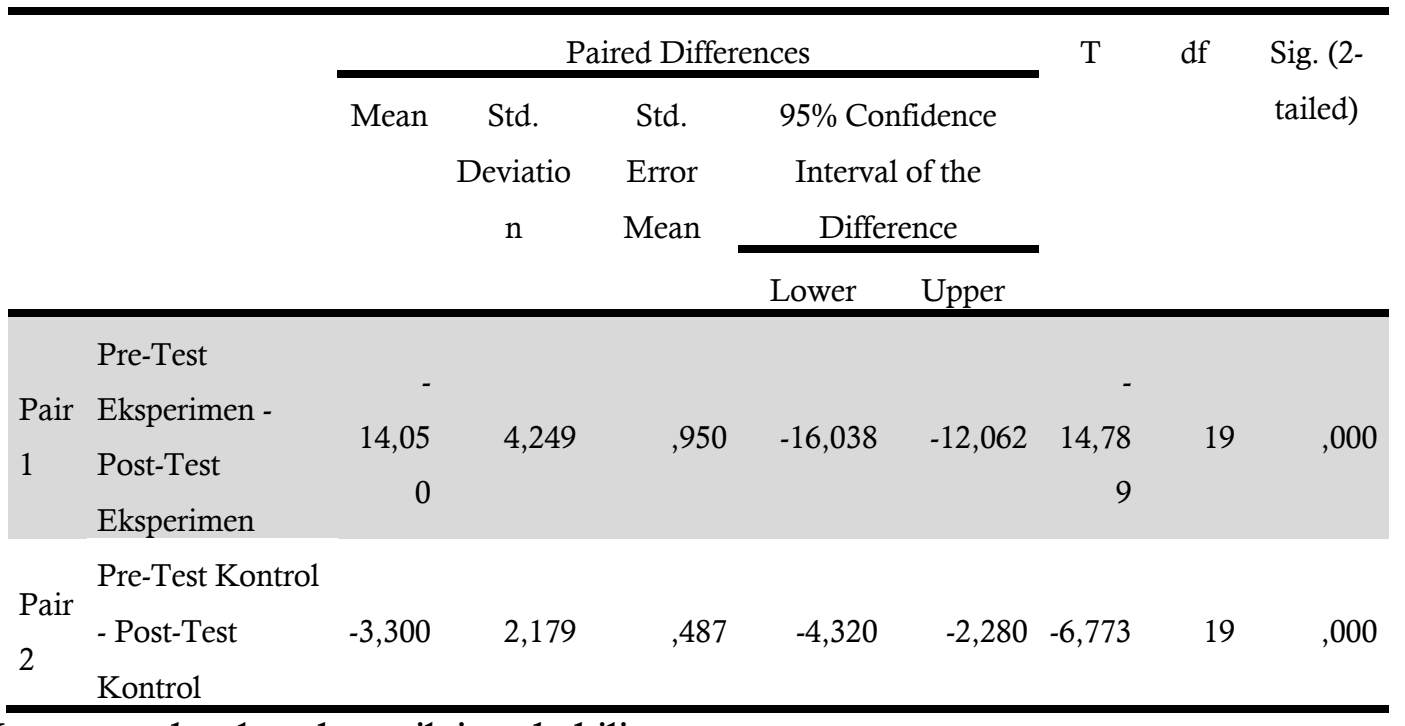

Keputusan berdasarkan nilai probability:

- Jika nilai sig. $<0.05$ maka Ho diterima

- Jika nilai sig. > 0.05 maka H1 ditolak

a). Berdasarkan output pair 1 diperoleh nilai sig. (2 - tailed) sebesar $0.000<0,05$ maka dapat disimpulkan ada perbedaan empati siswa untuk pretest kelas eksperimen dengan posttest kelas eksperimen.

b). Berdasarkan output pair 2 diperoleh nilai sig, ( 2 - tailed) sebesar $0.000<0.05$ maka dapat disimpulkan juga ada perbedaan empeti siswa untuk pretest kelas kontrol dengan posttest kelas kontrol.

c). Berdasarkan output pair 1 dan out put pair 2 diperoleh nilai mean pretest posttest kelas eksperimen senilai 14.050 lebih besar dari nilai mean pretest posttest kelas kontrol dengan nilai 3.300. Dengan demikian kelas eksperimen yang menggunakan model kooperatif tipe jigsaw lebih baik disandikan dengan kelas kontrol.

\section{Pembahasan}

Berdasarkan hasil penelitian yang diperoleh dapat terlihat bahwa baik kelompok kontrol maupun eksperimen sama-sama memberikan pengaruh terhadap sikap empati siswa, namun kelas eksperimen memberikan pengaruh yang lebih baik. Hal tersebut sejalan dengan penelitian Raharja (2017) yang menunjukkan pengaruh yang positif dari model kooperatif terhadap prilaku sosial siswa. 
Temuan dilapangan pada saat pelaksanaan penelitian menunjukkan bahwa dengan pembelajaran yang di desain secara berkelompok dengan disertai tugas yang diberikan memberikan tanggung jawab kepada siswa disetiap kelompok untuk dapat menuntaskan tugas yang diberikan dengan saling membatu, ketika kerjasama terjalin dengan baik pada saat itu proses interaksi terjadi, keinginan untuk membantu sesame anggota didalam kelompok menunjukkan adanya empati yang terbangun, dan hal tersebut harus senantiasa dilatih dan dibiasakan agar dapat menjadi suatu perilaku yang menetap. Berbeda dengan kelas control, dimana empati itu muncul hanya kepada teman dekatnya saja.

\section{KESIMPULAN}

Sikap empati merupakan sikap yang harus ditanamkan yang bagian dari makhluk sosial, dan untuk meningkatkan sikap empati dapat digunakan model kooperatif tipe jingsaw, hasil penelitian menunjukkan adanya perubahan sikap yang di tunjukkan siswa karena memang domain utama dari model kooperatif adalah untuk meningkatkan sikap afektif siswa yang tentu dalam hal ini salah satunya adalah empati. Penelitian ini tidak terlepas dari keterbatasan, sehingga perlu di lakukan penelitian selanjutnya dengan mempertimbangkan lokasi penelitian, jumlah sample dan pendekatan lain sebagai pembanding guna memperoleh hasil yang lebih baik dalam upaya meningkatkan sikap empati siswa.

\section{DAFTAR PUSTAKA}

A. Dale, Timpe. (1999). Seri Manajemen Sumber Daya Manusia. Yogyakarta: Gramedia.

Alsa, A. (2009). Pengaruh metode belajar Jigsaw terhadap keterampilan hubungan interpersonal dan kerjasama kelompok pada mahasiswa fakultas psikologi. Jurnal Psikologi UGM, 37(2), 131208.

Auliyah, A \& Flurentin, E. (2016). Efektivitas Penggunaan Media Film Untuk. Meningkatkan Empati Siswa Kelas VII SMP. Jurnal Kajian Bimbingan dan Konseling.

Frankel, Jack R dan Norman E. Wallen. (1993). How to design and Evaluate. Research in Education. 2nd edition. New York: McGraw hill Inc.

Solekhah, A. M., Atikah, T. P., \& Istiqomah, M. (2018). faktor-faktor yang mempengaruhi sikap empati terhadap perilaku prososial pada anak Sekolah Dasar. In Prosiding Seminar Nasional "Penguatan Pendidikan Karakter Pada Siswa Dalam Menghadapi Tantangan Global". Prosiding Seminar Nasional Kudus: Universitas Muria Kudus.

Raharja, Didik Subhakti Prawira. (2014). Pengaruh Model Cooperative Learning Tipe TGT dalam Pembelajaran Pendidikan Jasmani Terhadap Prilaku interaksi Sosial Siswa. Thesis.

Bandung:Universitas Pendidikan Indonesia

Raharja, D. S. P. (2017). Pengaruh model cooperative learning tipe tgt terhadap perilaku interaksi sosial siswa. Jurnal kependidikan jasmani dan olahraga, 1(1), 33-42. 
Roger, C.R. (1980). A way of Being. The lates thinking on a Person-Centered approach to life. Boston :hughton miffin company.

https://ugm.ac.id/id/berita/7649-empati-masyarakat-indonesia-sangat-kurang 